\title{
Pengaruh Pembelajaran Inkuiri dengan Scaffolding terhadap Keterampilan Proses Sains dan Pemahaman Konsep Siswa pada Materi Cahaya
}

\author{
Dimas Abdi Haidar ${ }^{1}$, Lia Yuliati ${ }^{2}$, Supriyono Koes Handayanto ${ }^{2}$ \\ ${ }^{1}$ Pendidikan Dasar-Universitas Negeri Malang \\ ${ }^{2}$ Pendidikan Fisika-Universitas Negeri Malang
}

\begin{tabular}{l}
\hline \hline INFO ARTIKEL \\
\hline Riwayat Artikel: \\
Diterima: $08-05-2020$ \\
Disetujui: $19-12-2020$ \\
\hline
\end{tabular}

Kata kunci:

inquiry; scaffolding;

science process skills;

inkuiri;

scaffolding;

keterampilan proses sains

\section{ABSTRAK}

\begin{abstract}
The purpose of this study is to examine the effect of inquiry learning with scaffolding on science process skills and understanding of light material concepts in fourth grade students. This type of research is a quasi-experimental design with a nonequivalent control group. The samples taken were students of class IV A (experimental) with 25 students and class IV B (control) with 22 students. The results of this study indicate that the value of science process skills and the percentage of students' understanding of concepts in light material in the experimental class have a significant increase compared to the control class. From the results of Man-Whitney and Anacova statistics it can be concluded that, there is a significant difference in the use of Inquiry learning with scaffolding of science process skills and understanding of light material concepts in fourth grade elementary school students.
\end{abstract}

\begin{abstract}
Abstrak: Tujuan dari penelitian ini yaitu untuk menguji pengaruh pembelajaran Inkuiri dengan scaffolding terhadap keterampilan proses sains dan pemahaman konsep materi cahaya pada siswa kelas IV. Jenis penelitian ini merupakan eksperimen semu dengan desain non-equivalent control group. Sampel yang diambil merupakan siswa kelas IV A (eksperimen) dengan 25 siswa dan kelas IV B (kontrol) dengan 22 siswa. Hasil penelitian ini menunjukan bahwa nilai keterampilan proses sains dan persentase pemahaman konsep siswa pada materi cahaya di kelas eksperimen memiliki peningkatan signifikan dibanding kelas kontrol. Dari hasil statistik Man-Whitney dan Anacova dapat diambil kesimpulan bahwa, ada perbedaan signifikan penggunaan pembelajaran Inkuiri dengan scaffolding terhadap keterampilan proses sains dan pemahaman konsep materi cahaya pada siswa kelas IV SD
\end{abstract}

\section{Alamat Korespondensi:}

Dimas Abdi Haidar

Pendidikan Dasar

Universitas Negeri Malang

Jalan Semarang 5 Malang

E-mail: dimashaidar147@gmail.com

Pelaksanaan pembelajaran dalam Kurikulum 2013 mengutamakan pengembangaan seluruh aspek kompetensi secara seimbang. Permendikbud Nomor 57 tahun 2014 menyatakan pembelajaran kurikuler dalam Kurikulum 2013 bertujuan mengembangkan kompetensi sikap, pengetahuan, dan keterampilan siswa. Salah satu muatan kurikuler di SD yang mencakup keseluruhan kompetensi siswa adalah Ilmu Pengetahuan Alam. Menurut Muslichach (2006) IPA diajarkan di jenjang SD bertujuan mengembangkan keingintahuan, sikap ilmiah, dan mengembangkan keterampilan proses ilmiah, sehingga siswa dapat membentuk pengetahuan untuk memahami gejala alam. Dengan demikian, muatan IPA di SD perlu diajarkan dengan mengembangkan aspek afektif, kognitif, dan psikomotor secara seimbang.

Pengembangan kompetensi sikap, pengetahuan, dan keterampilan dalam muatan pembelajaran IPA secara seimbang sejalan dengan hakikat sains yang memandang IPA sebagai sikap, produk, dan proses. Pada hakikatnya muatan IPA dipelajari sebagai sebuah nilai atau sikap ilmiah, sebagai produk yang berupa pengetahuan tentang fakta dan konsep, dan sebagai proses yang di dalamnya meliputi aktivitas atau proses ilmiah dalam mempelajari fenomena alam (Trianto, 2009; Tursinawati, 2016; Af'idayani, Setiadi, \& Fahmi, 2018; Brunner, \& El-Khalick, 2019). Oleh karena itu, pelaksanaan pembelajaran IPA perlu dirancang dan disajikan kepada siswa untuk mengakomodasi perkembangan sikap, pengetahuan dan keterampilan secara seimbang (Darmaji, dkk., 2019). Aspek pengetahuan dan keterampilan merupakan dua kompetensi utama yang harus dicapai dalam pembelajaran IPA di jenjang sekolah dasar (Yumuşak, 2016; Af'idayani, Setiadi, \& Fahmi, 2018). Hal tersebut didasarkan pada muatan materi dalam pembelajaran IPA yang membutuhkan keterampilan proses penyelidikan atau aktivitas ilmiah untuk menguasai pengetahuan yang berupa konsep, prinsip, teori, dan hukum (Shahali, dkk., 2015; Misbah, dkk., 2018). 
Dalam mempelajari IPA, siswa perlu menguasai keterampilan proses sains yang baik untuk mencapai penguasaan konsep secara bermakna. Menurut Nwosu \& Okeke (1995) Keterampilan Proses Sains didefinisikan sebagai kecakapan kognitif dan psikomotorik guna membantu dalam melakukan penyelidikan dan kegiatan ilmiah untuk mencapai penguasaan konsep dan pemecahan masalah sehari-hari. Menurut Yumuşak (2016) keterampilan proses sains melibatkan kapasitas anak melaksanakan serangkaian aktivitas yang bertujuan mencari informasi ilmiah sehingga dapat memperoleh suatu pengetahuan. Keterampilan proses sains dibutuhkan dalam pelaksanaan pembelajaran IPA karena meliputi kemampuan untuk mendukung kegiatan ilmiah seperti observasi, merumuskan dugaan, mengumpulkan informasi (bereksperimen), menganalisis data, dan menyusun kesimpulan (Güler, \& Şahin, 2019). Keterampilan Proses Sains siswa yang tinggi dapat berpengaruh pada peningkatan pemahaman konsep materi IPA yang lebih baik sebagai dampak keberhasilan dari kegiatan belajar siswa yang efektif. Penguasaan keterampilan proses sains memungkinkan setiap individu untuk mendapatkan pengalaman belajar berkesan dan kemampuan yang dibutuhkan untuk menyelesaikan permasalahan yang dihadapi dan menguasai konsep (Kazeni, 2005); Tilakaratne, \& Ekanayake, 2017).

Aspek Keterampilan Proses Sains berkaitan erat dengan pemahaman konsep yang diperoleh siswa. Pemahaman konsep adalah kompetensi pokok dalam IPA di SD sebab pengetahuan pada pembelajaran IPA dikonstruksi dan dipahami siswa dalam bentuk konsep-konsep. Menurut Kara \& Yeşilyurt (2008) pembelajaran IPA bertujuan memfasilitasi siswa meningkatkan pemahaman konsep yang bermakna dan membuat siswa memahami bagaimana pengaplikasian konsep di kehidupan sehari-hari. Konsep adalah unsur pengetahuan esensial yang terkandung dalam muatan materi IPA. Menurut Slavin (2006) konsep didefinisikan sebagai gagasan abstrak yang digeneralisasi dari contoh dan ciri-ciri yang spesifik. Dalam proses pembelajaran IPA, siswa akan mempelajari berbagai konsep untuk menjelaskan suatu peristiwa. Gagne (dalam Suparno, 2013), menyatakan bahwa belajar konsep adalah proses untuk mengetahui dan mengidentifikasi persamaan karakteristik suatu hal sebagai anggota suatu golongan. Oleh sebab itu, perencanaan pembelajaran IPA seharusnya berorientasi terhadap pemahaman konsep agar siswa dapat menjelaskan fenomena-fenomena di lingkungan sekitar dengan menggunakan bahasanya.

Pelaksanaan pembelajaran IPA di SD menuntut guru untuk dapat mengakomodasi aspek keterampilan proses meliputi aktivitas penyelidikan dan penemuan sehingga mampu meningkatkan pemahaman konsep siswa (Khan, 2012; Zeidan, \& Jayosi, 2015; Alhudaya, Hidayat, \& Koeshandayanto, 2018). Namun, pada kenyataanya guru seringkali menyajikan pembelajaran yang berfokus pada pencapaian Kriteria Kelulusan Minimum dan mengesampingkan aspek keterampilan proses sains siswa (Darmaji, dkk., 2019). Penelitian terdahulu telah mengidentifikasi bahwa guru sangat jarang menerapkan kegiatan yang dapat mengembangkan aspek Keterampilan Proses Sains dan pemahaman konsep siswa saat pembelajaran (Setyawati, dkk., 2014; Alhudaya, dkk., 2018; Wijayaningputri, dkk., 2018). Hasil survei pra penelitian Dewi, Sadia, \& Ristiati, (2013) menyatakan proses pembelajaran IPA di kelas secara umum hanya bertujuan menghafal pengetahuan dan mengesampingkan proses mendapatkan pengetahuan secara berkualitas. Paradigma pelaksanaan proses belajar tersebut membuat Keterampilan Proses Sains siswa tidak berkembang dan mengakibatkan kurang bermaknanya proses pemerolehan konsep IPA siswa. Hal tersebut mengindikasikan belum efektifnya guru dalam merancang dan melaksanakan kegiatan pembelajaran dengan muatan IPA. Oleh sebab itu, dibutuhkan penerapan bentuk pembelajaran yang dapat mengembangkan kompetensi pembelajaran siswa secara keseluruhan (Anggareni, Ristiati, \& Widiyanti, 2013).

Pembelajaran IPA di SD hendaknya menerapkan bentuk belajar yang efektif mengembangkan aspek Keterampilan Proses Sains dan pemahaman konsep. Warpala (2006) menyatakan bahwa ciri pembelajaran yang efektif untuk memahami konsep IPA salah satunya adalah aktivitas belajar berbasis Inkuiri (penyelidikan) untuk mempelajari konsep, dan melibatkan aktifitas fisik dan mental dalam melakukan penyelidikan. Bentuk pembelajaran yang mencakup ciri belajar konsep efektif salah satunya adalah pembelajaran Inkuiri. Oleh sebab itu, penerapan pembelajaran Inkuiri dalam penelitian ini diharapkan dapat mengoptimalkan peningkatan Keterampilan Proses Sains dan pemahaman konsep IPA pada siswa. Pembelajaran Inkuiri yang diterapkan secara optimal dapat menuntun siswa memperoleh pemahaman konsep secara mendalam dan bermakna (Justice, dkk., 2009). Jenis Inkuiri yang digunakan merupakan Inkuiri bebas (free Inquiry) dengan enam langkah pembelajaran, yaitu (1) mengamati masalah; (2) membuat rumusan masalah; (3) merumuskan praduga jawaban sementara (berhipotesis); (4) mengumpulkan data (eksperimen); (5) menentukan hipotesis yang diterima; dan (6) menyusun kesimpulan (Sund, \& Trowbridge, 1973; Sanjaya, 2006). Tahap pembelajaran Inkuiri memuat kegiatan ilmiah yang melibatkan siswa untuk mengamati, mengungkapkan permasalahan, mengajukan dugaan jawaban, bereksperimen, dan menentukan dugaan jawaban yang diterima untuk memperoleh suatu pengetahuan yang benar (Purnamawati, Ertikanto, \& Suyatna, 2017).

Proses pembelajaran Inkuiri yang lebih mandiri akan meningkatkan pemahaman konsep karena pengetahuan yang diperoleh didasari pada keingintahuan dan proses penyelidikan yang siswa lakukan (Binson, 2009; Arditama, dkk., 2018). Selain meningkatkan pemahaman konsep, langkah-langkah pembelajaran Inkuiri yang disajikan secara sistematis dapat melatih siswa membiasakan diri dengan proses ilmiah sehingga dapat mengembangkan Keterampilan Proses Sains siswa (Harahap, dkk., 2016). Beberapa temuan penelitian terdahulu menunjukkan, penerapan Inkuiri terbukti memiliki dampak positif dalam meningkatkan keterampilan proses IPA siswa secara signifikan (Abdi, 2014; Wijayaningputri, dkk., 2018; Güler, \& Şahin, 2019; Gunawan, dkk., 2019), dan meningkatkan pemahaman konsep siswa lebih baik daripada pembelajaran konvensional (Anggareni, dkk., 2013; Dewi, dkk., 2013; Antasari, 2017). Sementara itu, hasil penelitian lain membuktikan penerapan pemmbelajaran Inkuiri memiliki dampak positif terhadap peningkatan Keterampilan Proses Sains sekaligus pemahaman konsep siswa secara signifikan dalam suatu pembelajaran (Tangkas, 2012; Setyawati, dkk., 2014; Af'idayani, Setiadi, \& Fahmi, 2018; Alhudaya, 
Hidayat, \& Koeshandayanto, 2018). Hasil penguasaan Keterampilan Proses Sains dan pemahaman konsep siswa melalui penggunaan pembelajaran Inkuiri selama ini dapat dikatakan belum optimal. Beberapa penelitian menyatakan bahwa penerapan pembelajaran Inkuiri mempunyai kelemahan yang berpotensi untuk menghambat tercapainya tujuan pembelajaran secara keseluruhan sehingga tidak menimbulkan perbedaan dengan pembelajaran konvensional (Germann, 1989).

Penelitian Güler \& Şahin (2019) menyatakan bahwa, pada pembelajaran Inkuiri siswa dituntut menggunakan keterampilan proses secara mandiri dalam mengonstruksi pengetahuan walaupun kegiatan dilaksanakan secara berkelompok sehingga hasil pembelajaran sangat bergantung kepada kemampuan individu. Hasil penelitian Rustaman (2005) menunjukkan bahwa pembelajaran Inkuiri tidak dapat meningkatkan pemahaman konsep dengan efektif jika tidak dirancang secara optimal untuk mengakomodasi kendala yang dialami setiap siswa. Hasil penelitian Yildirim (2012) mengungkapkan, sebagian besar siswa menghadapi kesulitan dalam menyesuaikan diri dengan aktivitas belajar Inkuiri sehingga tidak ditemukan perbedaan yang nyata antara Keterampilan Proses Sains pada kelas yang menerapkan pembelajaran inkuiri dengan pembelajaran konvensional. Menurut Sanjaya (2006) kelemahan utama penerapan pembelajaran Inkuiri yaitu keberhasilan belajar ditentukan oleh kemampuan masing-masing individu untuk mengonstruksi konsep pengetahuan dalam dirinya. Oleh sebab itu, diperlukan bantuan belajar untuk mendukung siswa menyelesaikan permasalahan yang dihadapi selama melakukan kegiatan pada pembelajaran Inkuiri.

Salah satu bentuk bantuan belajar bagi siswa yang mengalami kesulitan mengonstruksi pemahaman adalah scaffolding. Vygotsky (dalam Suyono, \& Hariyanto, 2012) menyatakan bahwa scaffolding merupakan sebuah teknik pemberian bantuan yang dilakukan oleh seseorang yang lebih ahli agar pebelajar dapat menuju Zone of Proximal Development (ZPD) atau pengembangan kemampuan anak satu tingkat lebih tinggi. Pemilihan bantuan belajar scaffolding didasari pada beberapa kelebihan yang dimiliki. Kelebihan menerapkan scaffolding dalam pembelajaran menurut Bransford, dkk (2000) yaitu (1) menyediakan panduan yang mendukung siswa memfokuskan diri dalam mencapai tujuan pembelajaran; (2) mengurangi frustasi atau risiko kegagalan; (3) mendefinisikan dengan jelas tujuan aktifitas yang akan dilakukan untuk menguasai pengetahuan. Berdasarkan uraian tersebut, penerapan pembelajaran Inkuiri dengan scaffolding dilaksanakan sebagai upaya dalam meningkatkan Keterampilan Proses Sains dan pemahaman konsep siswa. Penerapan pembelajaran Inkuiri dengan scaffolding dalam penelitian ini dilaksanakan pada muatan pembelajaran IPA yaitu materi cahaya. Penelitian ini bertujuan menguji pengaruh penggunaan pembelajaran Inkuiri dengan scaffolding terhadap Keterampilan Proses Sains dan pemahaman konsep materi cahaya siswa kelas IV SD.

\section{METODE}

Penelitian ini menggunakan jenis eksperimen semu dengan desain non-equivalent control group. Eksperimen dilaksanakan untuk menguji pengaruh pembelajaran Inkuiri dengan scaffolding dibandingkan kelas tanpa pembelajaran Inkuiri dengan scaffolding terhadap Keterampilan Proses Sains dan pemahaman konsep materi cahaya pada siswa kelas IV SD. Dalam tahap awal, dilakukan penentuan sampel meliputi kelompok eksperimen dan kelompok kontrol. Penentuan sampel penelitian dilaksanakan dengan teknik pusposive sampling. Kriteria pemilihan sampel yaitu kelas yang memiliki kemampuan hasil belajar homogen berdasarkan hasil uji homogenitas. Sebelum perlakuan dilaksanakan, diberikan pretest terlebih dahulu untuk mengetahui Keterampilan Proses Sains dan pemahaman konsep awal siswa di kedua kelas sebelum perlakuan. Perlakuan berupa penerapan pembelajaran Inkuiri dengan scaffolding diberikan kepada kelompok eksperimen, sedangkan penerapan pembelajaran konvensional diterapkan pada kelompok kontrol. Setelah perlakuan selesai, dilaksanakan posttest yang bertujuan mengukur peningkatan Keterampilan Proses Sains dan pemahaman konsep siswa pada materi cahaya di masing-masing kelas. Rancangan penelitian ini termuat pada gambar 1.

$$
\frac{O_{1}}{O_{2}}-\frac{X_{1}}{X_{2}}-\frac{O_{3}}{O_{4}}
$$

Gambar 1. Desain Quasi Experimental Non-Equivalent Control-Group

Keterangan:

$\mathrm{O}_{1}=$ pretest kelompok eksperimen

$\mathrm{O}_{2}=$ pretest kelompok kontrol

$\mathrm{X}_{1}=$ treatment kelompok eksperimen (pembelajarann Inkuiri dengan scaffolding)

$\mathrm{X}_{2}=$ treatment kelompok kontrol (pembelajaran konvensional)

$\mathrm{O}_{3}=$ posttest kelompok eksperimen

$\mathrm{O}_{4}=$ posttest kelompok kontrol 
Penelitian ini dilaksanakan di SD Islam Surya Buana Malang, Jawa Timur. Sampel penelitian terdiri dari kelas IV A (25 siswa) dan kelas IV B (22 siswa). Kelas yang dipilih sebagai sampel penelitian telah memenuhi kriteria yaitu memiliki kemampuan homogen yang ditentukan dari hasil tes homogenitas. Berdasarkan uji homogenitas dengan rumus Levene test, diperoleh nilai Sig. lebih besar dari batas penolakan $\alpha$ yaitu 0,429>0,05 sehingga dapat dikatakan siswa di kedua kelas tersebut tidak mempunyai perbedaan varian prestasi belajar atau memiliki kemampuan yang homogen. Selanjutnya, kelas eksperimen dan kelas kontrol ditentukan melalui proses pengundian. Berdasarkan hasil pengundian, ditentukan kelas IV A sebagai kelas eksperimen dan kelas IV B sebagai kelas kontrol.

Penelitian ini menggunakan instrumen tes Keterampilan Proses Sains yang memuat empat soal esai dan satu soal unjuk kerja berkaitan dengan proses ilmiah untuk menyelidiki materi cahaya yang telah melalui validasi ahli, sedangkan instrumen tes pemahaman konsep memuat 13 butir soal yang mewakili setiap muatan konsep dalam materi cahaya. Instrumen tes pemahaman konsep berbentuk tes Three-tier yang telah melalui proses validasi ahli oleh dua orang validator ahli bidang penilaian pendidikan IPA dan ahli materi IPA. 13 butir soal Instrumen tes pemahaman konsep juga dinyatakan valid berdasarkan hasil validasi empirik yang diujikan pada siswa yang telah menerima pembelajaran materi cahaya dan bukan merupakan sampel yaitu siswa kelas V SD. Berdasarkan uji reliabilitas, didapatkan nilai koefisien butir tes pemahaman konsep sebesar 0.860 sehingga dapat dinyatakan keseluruhan item tes pemahaman konsep dikategorikan mempunyai reliabilitas tinggi. Instrumen lain yang digunakan sebagai pedoman penerapan pembelajaran Inkuiri dengan scaffolding adalah Lembar Kerja Peserta Didik (LKPD) "Sifat Cahaya". LKPD pada penelitian ini dirancang berdasarkan langkah-langkah pembelajaran Inkuiri yang telah dilengkapi dengan scaffolding di setiap tahap pembelajaran Inkuiri (kecuali pada tahap orientasi masalah). Instrumen LKPD "Sifat Cahaya" telah melalui proses validasi oleh dua validator ahli dengan skor total 3,72 atau termasuk dalam kategori sangat valid, sehingga instrumen LKPD dapat dipakai dalam proses pengambilan data.

Hasil data jawaban tes Keterampilan Proses Sains siswa dari kedua kelas yang dilaksanakan sebelum dan sesudah perlakuan kemudian dinilai dan dianalisis untuk mengukur aspek Keterampilan Proses Sains siswa di kedua kelas. Sementara itu, data hasil jawaban tes Three-tier yang dilaksanakan sebelum dan sesudah perlakuan dianalisis menggunakan pedoman penilaian tes Three-tier untuk mengetahui pemahaman konsep siswa di kedua kelas. Pengujian pengaruh pembelajaran Inkuiri dengan scaffolding terhadap Keterampilan Proses Sains dan pemahaman konsep materi cahaya pada siswa kelas IV dilakukan analisis data uji ANACOVA (Analysis of Covariance) atau uji non parametrik yang relevan. Sebelum data dianalisis menggunakan uji Anacova, perlu dilaksanakan uji asumsi klasik atau uji prasyarat yang terdiri dari uji normalitas data dan homogenitas varian pada data penelitian. Hasil perolehan uji statistik Anacova tersebut kemudian dijadikan sebagai acuan penentuan adakah pengaruh signifikan penerapan pembelajaran Inkuiri dengan scaffolding terhadap Keterampilan Proses Sains dan pemahaman konsep materi cahaya pada siswa kelas IV SD.

\section{HASIL}

Penelitian ini dilaksanakan di SD Islam Surya Buana Malang pada jenjang Kelas IV. Siswa di kelas IV A sebagai kelas eksperimen dibelajarkan menggunakan pembelajaran Inkuiri dengan scafffolding dan siswa di kelas IV B sebagai kelas kontrol dibelajarkan dengan pembelajaran yang biasa diterapkan sehari-hari (konvensional). Proses pembelajaran dalam penelitian ini dilaksanakan sebanyak enam kali pertemuan yang dilakukan secara tematik dengan muatan materi cahaya sebagai fokus pembelajaran. Siswa di kelas eksperimen melaksanakan pembelajaran Inkuiri dengan scaffolding secara berkelompok (4-5 anak) sesuai kegiatan dalam LKPD. Pembelajaran Inkuiri pada kelas eksperimen diterapkan melalui enam tahap, meliputi (1) orientasi masalah; (2) menyususn rumusan permasalahan; (3) menyusun praduga jawaban sementara (berhipotesis); (4) mengumpulkan informasi (eksperimen); (5) menentukan hipotesis yang diterima; (6) menyusun kesimpulan (Sund, \& Trowbridge, 1973; Sanjaya, 2006). Bantuan scaffolding yang diberikan dalam pembelajaran Inkuiri diberikan dalam bentuk scaffolding tertulis, scaffolding langsung, dan peer scaffolding (scaffolding teman sejawat). Bentuk scaffolding secara tertulis diberikan di setiap tahap pembelajaran Inkuiri (kecuali pada tahap orientasi masalah) yang dimuat dalam LKPD berupa pertanyaan dan petunjuk untuk membantu siswa mencapai tujuan dari setiap tahap pembelajaran Inkuiri yang dilakukan. Bentuk scaffolding secara langsung diberikan oleh peneliti ketika terdapat kelompok yang mengalami kesulitan saat pembelajaran berlangsung. Bentuk scaffolding dari teman sejawat selalu dilakukan disetiap akhir pertemuan yang bertujuan menguatkan konsep yang diperoleh siswa selama kegiatan pembelajaran. Scaffolding dari teman sejawat dilakukan dengan meminta siswa dalam satu kelompok yang telah memahami konsep untuk memberikan penjelasan kembali kepada teman sekelompoknya.

Pembelajaran di kelas kontrol dilaksanakan seperti pembelajaran yang biasa dilakukan siswa sehari-hari (konvensional). Pembelajaran pada kelas kontrol didominasi dengan kegiatan ceramah, diskusi, dan penugasan. Siswa kelas kontrol memulai pembelajaran dengan pengantar yang diberikan guru tentang aktivitas belajar yang hendak dilaksanakan. Siswa mendengar penyampaian materi secara verbal di depan kelas tentang konsep-konsep cahaya dari guru. Siswa diminta membaca teks bacaan tentang materi cahaya yang terdapat dalam buku. Guru membimbing siswa mengamati ilustrasi di buku yang menggambarkan konsep cahaya yang dipelajari. Siswa diminta membuat catatan rangkuman konsep pokok yang telah diajarkan dalam buku masing-masing. Siswa melakukan tanya jawab dengan guru tentang konsep-konsep cahaya yang tidak dimengerti. Siswa ditugaskan mengisi latihan soal dalam buku materi, kemudian dibahas bersama-sama. 
Selama pembelajaran muatan materi cahaya yang dilaksanakan empat kali pertemuan, siswa kelas kontrol mengikuti pembelajaran secara pasif. Tidak ada kegiatan yang dilakukan siswa untuk mengonstruksi pengetahuan atau konsep. Pengetahuan dan konsep yang disajikan pada siswa berbentuk pengetahuan sudah jadi melalui penyampaian guru dan sajian teks di buku. Kegiatan diskusi hanya terjadi dengan guru ketika terdapat siswa yang tidak mengerti tentang materi cahaya, sedangkan kegiatan diskusi bersama teman sebaya sangat jarang terjadi. Siswa kelas kontrol hanya dapat mengingat konsep melalui buku teks dan catatan di buku masing-masing. Partisipasi siswa dalam kelas kontrol selama penelitian tampak kurang kondusif, karena terdapat 6-7 siswa yang gaduh di saat guru menerangkan materi.

Untuk mengetahui pengaruh masing-masing perlakuan yang diterapkan terhadap aspek Keterampilan Proses Sains dan pemahaman konsep siswa pada materi cahaya, maka diberikan kegiatan pretest dan posttest. Pretest yang terdiri dari tes keterampilan porses sains berupa lima soal uraian dan tes pemahaman konsep siswa berupa 13 soal tes Three-tier diberikan pada siswa di kelas eksperimen dan kontrol sebelum perlakuan dilaksanakan. Sesudah pemberiann pretest, perlakuan dilaksanakan dengan menerapkan pembelajaran Inkuiri dengan scaffolding pada IV A dan pembelajaran konvensional pada kelas IV B. Kegiatan postets dengan instrumen yang sama dilaksanakan pada kedua kelas sesudah perlakuan selesai dilaksanakan. Berdasarkan hasil kegiatan pretest dan postest, diperoleh perbandingan kompetensi awal sebelum dan sesudah perlakuan untuk aspek Keterampilan Proses Sains dan pemahaman konsep siswa tentang materi cahaya pada kelas IV A dan kelas IV B.

Tabel 1. Persentase Keterampilan Proses Sains Siswa di Setiap aspek

\begin{tabular}{clcccc}
\hline \multirow{2}{*}{ No. } & \multirow{2}{*}{ Aspek Keterampilan Proses } & \multicolumn{2}{c}{ Kelas Eksperimen } & \multicolumn{2}{c}{ Kelas Kontrol } \\
\cline { 3 - 5 } & & pretest & posttest & pretest & posttest \\
\hline 1 & Keterampilan merumuskan masalah & 32 & 85 & 30,1 & 73 \\
2 & Keterampilan menyusun hipotesis & 26,4 & 85 & 26,8 & 65 \\
3 & Keterampilan mencoba (bereksperimen) & 33,1 & 87 & 37,7 & 80 \\
4 & Keterampilan Menentukan hipotesis yang benar & 42 & 84 & 44,3 & 70 \\
5 & Keterampilan Menyimpulkan & 29 & 90 & 27 & 80 \\
\hline \multicolumn{2}{c}{ Rata-rata total } & 32,5 & 86,2 & 33,3 & 73,6 \\
\hline
\end{tabular}

Tabel 2. Persentase Pemahaman Konsep Siswa di Setiap Indikator Konsep

\begin{tabular}{|c|c|c|c|c|c|}
\hline \multirow{2}{*}{ No. } & \multirow{2}{*}{ Indikator Konsep Cahaya } & \multicolumn{2}{|c|}{ Kelas Eksperimen \% } & \multicolumn{2}{|c|}{ Kelas Kontrol \% } \\
\hline & & Pretest & Posttest & Pretest & Posttest \\
\hline 1. & Cahaya merambat tanpa memerlukan medium. & 20 & 64 & 27,2 & 59,1 \\
\hline 2. & Sumber cahaya alami dan sumber cahaya buatan. & 44 & 80 & 54,5 & 54,5 \\
\hline 3. & Sifat cahaya merambat lurus. & 68 & 96 & 72,7 & 81,8 \\
\hline 4. & Sifat cahaya menembus benda bening. & 40 & 96 & 40,1 & 77,3 \\
\hline 5. & Sifat cahaya dapat dipantulkan. & 68 & 92 & 81,8 & 100 \\
\hline 6. & Pemantulan cahaya pada cermin datar. & 60 & 84 & 68 & 77,3 \\
\hline 7. & Pemantulan cahaya pada cermin cembung. & 8 & 48 & 18 & 54,5 \\
\hline 8. & Pemantulan cahaya pada cermin cekung. & 16 & 68 & 13,6 & 59,1 \\
\hline 9. & Cahaya yang dapat dibiaskan. & 12 & 92 & 22,7 & 81,8 \\
\hline 10. & Sifat cahaya dapat diuraikan. & 32 & 72 & 13,6 & 72,7 \\
\hline 11. & Manfaat penerapan sifat cahaya di lingkungan sekitar. & 32 & 96 & 22,7 & 59,1 \\
\hline 12. & Hubungan cahaya dengan proses pengelihatan. & 24 & 72 & 27,2 & 86,3 \\
\hline 13. & Sifat cahaya yang berperan dalam proses melihat. & 44 & 76 & 63,6 & 72,7 \\
\hline & Rata-rata total & 36 & 80 & 40,4 & 72 \\
\hline
\end{tabular}

Hasil data kegiatan pretest dan posttest pada tabel 1 dan 2 diuji normalitas dan homogenitas sebagai uji prasyarat (uji asumsi klasik) sebelum dilaksanakannya uji parametrik Anacova. Rekapitulasi hasil uji normalitas dengan rumus Shapiro-Wilk menggunakan SPSS 24 terhadap data Keterampilan Proses Sains dan pemahaman konsep termuat pada tabel 3.

Tabel 3. Rekapitulasi Hasil Uji Normalitas Data Keterampilan Proses Sains

\begin{tabular}{lccc}
\hline \multirow{2}{*}{\multicolumn{1}{c}{ Data }} & \multicolumn{3}{c}{ Shapiro-Wilk } \\
\cline { 2 - 4 } & Statistic & df & Sig. \\
\hline Pretest Kelas eksperimen (IV A) & .912 & 25 & .033 \\
Pretest Kelas kontrol (IV B) & .908 & 22 & .043 \\
Posttest Kelas eksperimen (IV A) & .904 & 25 & .023 \\
Posttest Kelas kontrol (IV B) & .922 & 22 & .083 \\
\hline
\end{tabular}


Tabel 4. Rekapitulasi Hasil Uji Normalitas Data Pemahaman Konsep

\begin{tabular}{lrrr}
\hline \multirow{2}{*}{ Data } & \multicolumn{3}{c}{ Shapiro-Wilk } \\
\cline { 2 - 4 } & Statistic & df & \multicolumn{1}{c}{ Sig. } \\
\hline Pretest Kelas eksperimen (IV A) & .961 & 25 & .437 \\
Pretest Kelas kontrol (IV B) & .913 & 22 & .055 \\
Posttest Kelas eksperimen (IV A) & .920 & 25 & .051 \\
Posttest Kelas kontrol (IV B) & .913 & 22 & .055 \\
\hline
\end{tabular}

Berdasarkan rekapitulasi uji normalitas pada tabel 3 diperoleh nilai Sig. pada keseluruhan data Keterampilan Proses Sains siswa lebih kecil dari batas penolakan $(0,05)$, sehingga dapat dinyatakan data Keterampilan Proses Sains siswa tidak terdistribusi secara normal. Untuk hasil pengujian homogenitas menggunakan rumus levene test terhadap data Keterampilan Proses Sains menunjukkan nilai Sig. data pretest sebesar 0,01 dan signifikansi posttest sebesar 0,027. Hasil tersebut menunjukan nilai signifikansi data Keterampilan Proses Sains siswa lebih kecil dari batas penolakan $(0,05)$, sehingga dapat disimpulkan data tersebut tidak homogen. Karena data keterampilan proses sains siswa tidak memenuhi prasyarat normalitas dan homogenitas data, maka analisis data dilakukan dengan statistik non parametrik. Statistik non parametrik yang dipakai menganalisis data Keterampilan Proses Sains siswa pada penelitian ini adalah uji Man-Whitney karena data berasal dari kelompok yang berbeda atau independen.

Uji normalitas data yang termuat pada tabel 4 menunjukkan nilai Sig. pada keseluruhan data pemahaman konsep siswa dalam materi cahaya lebih besar dari batas penolakan $(0,05)$, maka dapat dinyatakan data pemahaman konsep siswa pada penelitian ini terdistribusi secara normal. Selanjutnya, pada data pemahaman konsep yang sama dilakukan uji homogenitas. Hasil uji homogenitas dengan rumus levene test menggunakan data pemahaman konsep diperoleh nilai Sig. pretest pemahaman konsep sebesar 0,902 dan nilai Sig. data posttest pemahaman konsep sebesar 0,218. Berdasarkan hasil uji homogenitas tersebut, nilai signifikansi data pemahaman konsep siswa lebih besar dari batas penolakan (0,05), maka dapat disimpulkan data pemahaman konsep materi cahaya siswa adalah homogen. Karena data pemahaman konsep siswa telah memenuhi uji prasyarat normalitas dan homogenitas, maka analisis data pemahaman konsep dalam penelitian ini memakai statistik parametrik berupa uji Anacova. Statistik non parametrik untuk menguji pengaruh pembelajaran Inkuiri dengan scaffolding terhadap Keterampilan Proses Sains siswa dalam penelitian ini menggunakan Man-Whitney test. Ringkasan hasil uji statistik Man-Whitney dengan data Keterampilan Proses Sains siswa termuat dalam tabel 5.

Tabel 5. Hasil Uji Man-Whitney pada Data Keterampilan Proses Sains

\begin{tabular}{lrr}
\hline Test Statistics & pretest_KPS & \multicolumn{1}{c}{ posttest_KPS $^{\text {a }}$} \\
\hline Mann-Whitney $U$ & 258.000 & 46.500 \\
$Z$ & -.375 & -4.935 \\
Asymp. Sig. (2-tailed) & .708 & .000 \\
\hline a. Grouping Variable: Kelas & & \\
\hline
\end{tabular}

Pada hasil uji Man-Whitney dengan data Keterampilan Proses Sains siswa dalam pembelajaran materi cahaya, didapatkan nilai Asymp Sig. data pretest_KPS sebesar 0,708 dan nilai Assymp Sig. data postest_KPS yaitu sebesar 0,000. Selanjutnya, hasil tersebut dikonsultasikan dengan tingkat signifikan $\alpha$ yaitu 0,05. Dari hasil uji Man-Whitney, dapat diketahui Asymp Sig data pretest_KPS lebih besar dari tingkat signifikan $\alpha(0,708>0,05)$, jadi dapat disimpulkan nilai Keterampilan Proses Sains pada kelas eksperimen (IV A) dan kelas kontrol (IV B) sebelum perlakuan diberikan tidak memiliki perbedaan signifikan. Hasil tersebut membuktikan jika nilai Keterampilan Proses Sains yang diperoleh kedua kelas sebelum pemberian perlakuan cenderung serupa atau tidak berbeda secara nyata. Data nilai Keterampilan Proses Sains siswa pada tabel 1 menunjukan rerata persentase untuk kelas eksperimen adalah 32,5\% dan pada kelas kontrol adalah 33,3\%. Nilai Assymp Sig pada data posttest_KPS lebih kecil dibandingkan tingkat signifikansi alpha $(0,00<0,05)$, sehingga $\mathrm{H}_{0}$ (hipotesis nihil) ditolak dan $\mathrm{H}_{\mathrm{a}}$ (Hipotesis alternatif) yang menyatakan terdapat perbedaan signifikan Keterampilan Proses Sains siswa di kelas yang menggunakan pembelajaran Inkuiri dengan scaffolding dengan kelas tanpa menggunakan pembelajaran Inkuiri dengan scaffolding diterima. Selisih perbedaan nilai Keterampilan Proses Sains siswa yang signifikan dapat diketahui dari peningkatan nilai dalam kegiatan pretest dan posttest pada kelas eksperimen yang lebih besar dibanding dengan peningkatan nilai di kelas kontrol. Selisih peningkatan nilai Keterampilan Proses Sains antara kedua kelas tersebut sebesar 10,7. Hasil tersebut membuktikan bahwa penggunaan pembelajaran Inkuiri dengan scaffolding berpengaruh secara signifikan terhadap keterampilan proses sains siswa kelas IV SD Islam Surya Buana Malang.

Data pemahaman konsep siswa pada materi cahaya dalam penelitian ini telah memenuhi prasyarat untuk dianalisis memakai statistik parametrik. Pengujian statistik parametrik Anacova dilaksanakan menggunakan data pemahaman konsep siswa di kelas eksperimen (IV A) dan kelas kontrol (IV B) dengan data nilai pretest sebagai kovariat. Ringkasan hasil uji Anacova terhadap pemahaman konsep siswa termuat pada tabel 6. 
Tabel 6. Hasil Uji Anacova pada Data Pemahaman Konsep Siswa

\begin{tabular}{lrrr}
\hline \multicolumn{4}{c}{ Tests of Between-Subjects Effects: Anacova } \\
\hline Source & $\mathrm{df}$ & Mean Square & \multicolumn{1}{c}{ Sig. } \\
\cline { 2 - 4 } Corrected Model & 2 & 999.184 & .004 \\
Intercept & 1 & 25538.593 & .000 \\
Pretest pemahaman konsep & 1 & 1202.664 & .009 \\
Kelas & 1 & 1093.931 & .012 \\
\hline Error & 44 & 160.721 & \\
\hline Total & 47 & & \\
\hline
\end{tabular}

Hasil uji statistik pemahaman konsep siswa menggunakan uji Anacova pada tabel 6 menunjukan nilai signifikansi (Sig.) pada variabel Kelas sebesar 0,012. Hal tersebut menunjukan nilai Sig. variabel Kelas lebih kecil dibandingkan tingkat signifikan alpha $(0,012<0,05)$, sehingga hipotesis nihil $\left(\mathrm{H}_{0}\right)$ ditolak dan hipotesis alternatif $\left(\mathrm{H}_{\mathrm{a}}\right)$ yang berbunyi terdapat perbedaan signifikan pemahaman konsep siswa di kelas yang menerapkan pembelajaran Inkuiri dengan scaffolding dengan kelas yang tidak menerapkan pembelajaran Inkuiri dengan scaffolding diterima. Perbedaan yang signifikan dapat diketahui dari selisih peningkatan persentase pemahaman konsep siswa dalam kegiatan pretest dan posttest di kelas eksperimen yang lebih besar daripada kelas kontrol. Selisih peningkatan persentase pemahaman konsep yang terjadi antara kedua kelas tersebut adalah $12,4 \%$. Hasil tersebut membuktikan bahwa penggunaan pembelajaran Inkuiri dengan scaffolding berpengaruh signifikan terhadap pemahaman konsep siswa pada materi cahaya kelas IV SD Islam Surya Buana Malang. Untuk menguji pengaruh pengetahuan awal (pretest) terhadap pemahaman konsep pada materi cahaya setelah diberikan perlakuan dapat dilihat berdasarkan variabel pretest_pemahaman konsep. Variabel pretest_pemahaman konsep menunjukan nilai Sig. yang lebih kecil dibanding tingkat signifikansi alpha $(0,009<0,05)$. Jadi, dapat disimpulkan bahwa konsepsi awal siswa dalam materi cahaya di kelas eksperimen dan kelas kontrol memiliki pengaruh terhadap perolehan hasil pemahaman konsep siswa setelah penerapan perlakuan di masing-masing kelas. Untuk menguji pengaruh secara simultan (bersamaan) dari penggunaan pembelajaran Inkuiri dengan scaffolding dan konsepsi awal siswa pada (pretest) terhadap pemahaman konsep siswa pada materi cahaya dapat dilihat pada variabel Corrected Model. Nilai signifikansi pada variabel Corrected Model lebih kecil dari tingkat signifikansi alpha $(0,004<0,05)$. Oleh karena itu, dapat disimpulkan bahwa penggunaan pembelajaran Inkuiri dengan scaffolding dan konsepsi awal siswa (pretest) secara simultan memiliki pengaruh terhadap pemahaman konsep siswa kelas IV SD pada materi cahaya.

\section{PEMBAHASAN}

Hasil penelitian ini menunjukan bahwa terdapat perbedaan yang signifikan pada Keterampilan Proses Sains dan pemahaman konsep siswa dalam materi cahaya di kelas IV A (eskperimen) yang menerapkan pembelajaran Inkuiri dengan scaffolding dengan kelas IV B (kontrol) yang menerapkan pembelajaran konvensional. Hasil uji Man-Whitney yang telah dilakukan menunjukan nilai Asymp Sig data Keterampilan Proses Sains siswa lebih kecil dari tingkat signifikansi $(0,00<0,05)$, maka diperoleh kesimpulan bahwa ada perbedaan nilai Keterampilan Proses Sains siswa pada kelas eksperimen dan kelas kontrol. Rekapitulasi data statistik pada tabel 1 menunjukkan kedua kelas mengalami peningkatan nilai Keterampilan Proses Sains siswa setelah pemberian perlakuan. Peningkatan Keterampilan Proses Sains yang terjadi di kelas ekperimen lebih besar daripada peningkatan yang terjadi di kelas kontrol. Siswa di kelas eksperimen memiliki peningkatan nilai rerata Keterampilan Proses Sains sebesar 53,7, sedangkan pada kelas kontrol nilai rerata Keterampilan Proses Sains meningkat sebesar 40,3, dengan demikian selisih peningkatan rerata nilai Keterampilan Proses Sains siswa pada dua kelas tersebut adalah 13,4. Hasil tersebut menunjukkan bahwa penerapan pembelajaran Inkuiri dengan scaffolding lebih efektif untuk meningkatkan Keterampilan Proses Sains siswa dibandingkan pembelajaran konvensional.

Pembelajaran Inkuiri dengan scaffolding yang diberikan di kelas eksperimen memiliki peran penting dalam meningkatkan Keterampilan Proses Sains siswa. Serangkaian kegiatan ilmiah yang dilakukan selama penerapan pembelajaran Inkuiri terbukti efektif untuk meningkatkan keterampilan proses sains siswa (Sullivan, 2008; Yakar \& Baykara, 2014; Sribekti, dkk., 2016). Peningkatan Keterampilan Proses Sains pada siswa kelas eksperimen dalam penelitian ini merupakan pengaruh dari proses pembelajaran Inkuiri yang telah diterapkan siswa selama mempelajari materi cahaya. Menurut Iswatun, dkk (2017), aspek Keterampilan Proses Sains siswa dapat meningkat ketika siswa terbiasa belajar membangun pengetahuan melalui langkah-langkah ilmiah dengan mencari, menemukan, melakukan percobaan sistematis untuk membangun konsep. Pembelajaran melalui pengalaman langsung dengan mengamati, dan melakukan percobaan untuk membentuk pengetahuan merupakan cara efektif dalam mengembangkan aspek Keterampilan Proses Sains siswa (Ting, \& Siew, 2014). Scaffolding yang diberikan selama pembelajaran Inkuiri juga memiliki peran penting dalam peningkatan penguasaan Keterampilan Proses Sains siswa karena dapat memotivasi dalam menyelesaikan aktivitas belajar dengan maksimal. Hasil penelitian Kurnia, dkk (2019) menyimpulkan bahwa, scaffolding yang diberikan selama mempelajari konsep IPA dapat membantu siswa mengatasi kesulitan belajar dan mendukung penyelesaian tugas dengan baik di setiap kegiatan pembelajaran yang sedang dilaksanakan.

Pada awal pertemuan pembelajaran Inkuiri dengan scaffolding di kelas eksperimen, siswa sangat membutuhkan scaffolding baik dalam bentuk tertulis di LKPD dan scaffolding langsung dari guru. Hal tersebut terjadi karena sebagian besar siswa belum paham dengan maksud kegiatan belajar dan merasa kesulitan menyesuaikan diri dengan kegiatan pembelajaran 
Inkuiri yang baru diterapkan. Namun, pada pertemuan ketiga dan seterusnya, siswa mulai memahami maksud kegiatan yang dilakukan sehingga jarang sekali dilakukan scaffolding secara langsung dari guru. Penerapan scaffolding dalam penelitian ini didukung dengan pernyataan Slavin (2006) yang mengungkapkan bahwa, scaffolding merupakan bantuan dari seseorang yang lebih kompeten dalam pembelajaran, kemudian menghilangkannya ketika siswa dapat menyelesaikannya secara mandiri. Scaffolding dalam pembelajaran Inkuiri membantu siswa menyelesaikan kegiatan belajar dan tugas belajar sesuai tujuan, sehingga dapat membantu siswa memahami kegiatan ilmiah yang dilakukan (Mantik, \& Choi, 2017; Handayanto, dkk., 2018). Hasil penelitian ini menguatkan temuan penelitian terdahulu yang menyatakan bahwa, penggunaan pembelajaran Inkuiri dapat mengembangkan penguasaan tentang kinerja ilmiah, sehingga keterampilan proses sains siswa dapat meningkat (Lati, dkk., 2012; Bekiroğlu, \& Arslan, 2014; Nworgu, \& Otum, 2013; Griffin, \& Care, 2015; Hairida, 2016; Juhji, 2016; Savitri, dkk., 2017). Temuan ini juga menguatkan hasil penelitian lain yang menyatakan bahwa scaffolding yang diterapkan pada pembelajaran Inkuiri efektif untuk meningkatkan Keterampilan Proses Sains siswa (Saye, \& Brush, 2002; Simons, \& Klein, 2007; van-Uum, dkk., 2017).

Hasil uji Anacova dengan data pemahaman konsep siswa pada tabel 6 menunjukan nilai signifikansi variabel "Kelas" lebih kecil dari tingkat signifikansi alpha $(0,009<0,05)$. Hasil uji statistik Anacova tersebut menunjukan bahwa, ada perbedaan signifikan persentase pemahaman konsep dalam materi cahaya siswa kelas IV A yang menggunakan pembelajaran Inkuiri dengan scaffolding dan kelas IV B yang menggunakan pembelajaran konvensional. Data statistik pada tabel 2 menunjukkan terdapat peningkatan persentase pemahaman konsep siswa pada kedua kelas setelah diberikannya perlakuan. Selisih peningkatan persentase pemahaman konsep dalam materi cahaya yang dialami kelas eksperimen lebih besar dari peningkatan yang dialami di kelas kontrol. Peningkatan persentase pemahaman konsep yang dialami siswa kelas eksperimen yaitu 44\%, sedangkan siswa di kelas kontrol meningkat dengan persentase 31,6\%. Dengan demikian, selisih peningkatan persentase pada kedua kelas tersebut adalah 12,4\%. Hasil tersebut menunjukan bahwa penerapan pembelajaran Inkuiri dengan scaffolding pada kelas eksperimen lebih efektif untuk meningkatkan pemahaman konsep siswa pada materi cahaya daripada penerapan pembelajaran konvensional pada kelas kontrol.

Penerapan pembelajaran Inkuiri di kelas eksperimen mendukung siswa membangun pemahaman konsep dalam materi cahaya dengan lebih baik karena terlibat secara aktif dalam aktivitas penyelidikan yang otentik. Inkuiri memuat serangkaian proses yang saling terkait dimana siswa berperan sebagai ilmuwan yang mengajukan pertanyaan tentang fenomena alam dan menyelidikinya untuk memperoleh pengetahuan dan meningkatkan pemahaman konsep yang kaya (NRC, 1996; Çorlu, \& Corlu, 2012). Kegiatan ilmiah dalam pembelajaran Inkuiri di kelas eksperimen memfasilitasi siswa dalam memaksimalkan proses pembentukan konsep yang meliputi tahap asimilasi, akomodasi, dan ekuilibrasi. Pembentukan konsep siswa merupakan dampak dari skema proses kognitif meliputi tahap asimilasi, akomodasi, dan ekuilibrasi yang terjadi selama pembelajaran (Jalan, dkk., 2016). Menurut Piaget (1977), dalam skema perkembangan kognitif, pembentukan pengetahuan dalam diri anak dimulai dari tahap asimilasi dengan menerima fakta atau pengalaman baru dan memodifikasi skema dalam diri sesuai fakta atau pengalaman yang diterima pada tahap akomodasi sehingga dapat mencapai keseimbangan pengetahuan (ekuilibrasi). Menurut Metaputri \& Garminah (2016), pembelajaran Inkuiri dapat berperan penting dalam mengembangkan proses asimilasi dan akomodasi siswa antara pengetahuan yang dimiliki sebelum pembelajaran dengan temuan fakta baru sehingga menghasilkan pengetahuan yang lebih baik. Temuan ini menguatkan hasil penelitian terdahulu yang mengungkapkan bahwa penerapan pembelajaran Inkuiri yang memuat aktivitas ilmiah secara terstruktur dapat membantu siswa mengonstruksi konsep dengan efektif (Perkins, dkk., 2006; Minner, dkk., 2009; Juniati, \& Widiana, 2017; Antasari, 2017). Hasil penelitian Simsek \& Kabapinar (2010) membuktikan melalui data kuantitatif dan data empiris bahwa pembelajaran berbasis Inkuiri mampu meningkatkan pemahaman konsep IPA siswa SD. Penerapan Scaffolding selama pembelajaran Inkuiri memiliki peran penting dalam mendukung siswa yang menghadapi kesulitan memahami suatu konsep. Dengan scaffolding yang dilakukan di setiap tahap pembelajaran Inkuiri dapat mencegah siswa dari kesalahpahaman konsep (Bean, \& Stevens, 2002), dan dapat menjembatani kesulitan siswa dalam belajar konsep (Handayanto, 2013) sehingga siswa dapat membangun pemahaman konsep dengan lebih optimal. Penelitian terdahulu menyimpulkan bahwa, saat siswa secara aktif mengikuti proses pembelajaran Inkuiri yang digabungkan dengan bimbingan scaffolding dari pendidik, siswa dapat memperoleh pemahaman konsep IPA yang lebih baik (Martin-hansen, 2005; Correiro, dkk., 2008).

Hasil keseluruhan penelitian ini menunjukan bahwa, penggunaan pembelajaran Inkuiri dengan dilengkapi bimbingan scaffolding lebih efektif dalam meningkatkan Keterampilan Proses Sains dan pemahaman konsep siswa dalam materi cahaya daripada penerapan pembelajaran konvensional. Melalui kegiatan pembelajaran Inkuiri para siswa dapat memperoleh keterampilan proses ilmiah yang baik sehingga berpengaruh terhadap pemerolehan pemahaman konsepnya (Ergul, dkk., 2011; Yager, \& Akcay, 2010; Rizal, 2014). Menurut Schlenker (dalam Joyce, \& Weil, 2011) aktivitas belajar Inkuiri mampu mengembangkan pemahaman langkah kerja ilmiah dan kemampuan menganalisis informasi siswa, yang akan berdampak pada peningkatan keterampilan proses dan pemahaman terhadap suatu konsep. Hasil temuan ini menguatkan hasil penelitian VanDijk \& Lazonder (2016) dan Van-uum, dkk (2017) yang mengungkapkan bahwa peran penting guru dalam pembelajaran IPA berbasis Inkuiri adalah memberikan fasilitas bantuan belajar atau scaffolding pada siswa. Scaffolding dalam pembelajaran berbasis Inkuiri hendaknya bertujuan untuk membantu pemahaman konseptual, prosedur penyelidikan, dan cara pengetahuan ilmiah dihasilkan (Duschl, 2008); Furtak et al., 2012). 


\section{SIMPULAN}

Implementasi pembelajaran Inkuiri yang dilengkapi scaffolding dalam penelitian ini membantu siswa menyelesaikan kegiatan belajar dan tugas belajar sesuai tujuan, sehingga dapat mengembangkan penguasaan Keterampilan Proses Sains dan meningkatkan pemahaman konsep siswa dalam materi cahaya. Dari hasil penelitian ini disimpulkan bahwa, terdapat pengaruh penggunaan pembelajaran Inkuiri dengan scaffolding terhadap Keterampilan Proses Sains dan pemahaman konsep materi cahaya pada siswa kelas IV SDN Islam Surya Buana Malang. Hasil tersebut didukung data nilai Keterampilan Proses Sains dan persentase pemahaman konsep siswa pada kelas yang menerapkan pembelajaran Inkuiri dengan scaffolding memiliki peningkatan signifikan dibanding kelas dengan pembelajaran konvensional. Perbedaan peningkatan nilai Keterampilan Proses Sains dari hasil pretest dan posttest antara siswa di kelas Inkuiri dengan scaffolding dan kelas konvensional adalah 13,4, sedangkan selisih peningkatan persentase pemahaman konsep materi cahaya siswa pada kelas Inkuiri dengan scaffolding dan kelas konvensional adalah 12,4\%. Hasil uji statistik Man-Whitney dan Anacova yang telah dilakukan menunjukan ada perbedaan pengaruh yang signifikan penggunaan pembelajaran Inkuiri dengan scaffolding terhadap Keterampilan Proses Sains dan pemahaman konsep materi cahaya pada siswa kelas IV SDN Islam Surya Buana Malang.

Berdasarkan hasil penelitian ini, rekomendasi yang dapat diberikan yaitu diperlukan studi lanjutan mengenai pengaruh pembelajaran Inkuiri dengan scaffolding terhadap variabel lain yang mungkin dapat berkembang pada diri siswa selama pembelajaran berlangsung. Untuk penelitian selanjutnya, pemberian scaffolding dalam pembelajaran Inkuiri hendaknya dapat dirancang lebih sistematis dan dilaksanakan dengan bentuk lebih bervariasi agar siswa tidak merasa jenuh.

\section{DAFTAR RUJUKAN}

Abdi, A. (2014). The Effect of Inquiry-based Learning Method on Students' Academic Achievement in Science Course. Universal Journal of Educational Research, 2(1), 37-41. https://doi.org/10.13189/ujer.2014.020104

Af'idayani, N., Setiadi, I., \& Fahmi. (2018). The Effect of Inquiry Model on Science Process Skills and Learning Outcomes. European Journal of Education Studies, 4(12), 177-182. https://doi.org/10.5281/zenodo.1344846

Alhudaya, M. T., Hidayat, A., \& Koeshandayanto, S. (2018). Pengaruh Inkuiri Terbimbing terhadap Keterampilan Proses Sains dan Pemahaman Konsep Optik Siswa Kelas VIII. Jurnal Pendidikan: Teori, Penelitian, dan Pengembangan, 3(11), 13981404.

Anggareni, N. W., Ristiati, N. P., \& Widiyanti, N. L. P. M. (2013). Implementasi Strategi Pembelajaran Inkuiri terhadap Kemampuan Berpikir Kritis dan Pemahaman Konsep IPA Siswa Smp. E-Journal Program Pascasarjana Universitas Pendidikan Ganesha, 3(1), 1-11.

Antasari, N. (2017). Penerapan Model Inkuiri Terbimbing Siswa Kelas V. Jurnal Pendidikan Guru Sekolah Dasar, 2(3), 1-13.

Arditama, A. Y., Wardani, S., Purwanti, E., \& Hindarto, N. (2018). Storybook Influence on Science Concept Comprehension Through Curiosity of Fifth Grade Elementary School Student. Journal of Primary Education, 7(1), 1-9.

Bean, T. W., \& Stevens, L. P. (2002). Scaffolding Reflection for Preservice and Inservice Teachers. Reflective Practice, 3(2), 205-218. https://doi.org/10.1080/14623940220142343

Bekiroğlu, F. O., \& Arslan, A. (2014). Examination of the Effects of Model-Based Inquiry on Students 'Outcomes: Scientific Process Skills and Conceptual Knowledge. Procedia - Social and Behavioral Sciences 141, 141, 1187-1191. https://doi.org/10.1016/j.sbspro.2014.05.202

Binson, B. (2009). Curiosity-Based Learning (CBL) Program. US-China Education Review, 6(12), 13-22.

Borg, W. R., Gall, M. D., \& Gall, J. P. (2003). Educational Research: An Introduction Seventh edition. Pearson Education. https://doi.org/10.2307/3121583

Bransford, J. D., Brown, A. L., \& Cocking, R. R. (2000). How People Learn: Brain, Mind, and Experience \& School. National Academy Press.

Brunner, J. L., \& El-Khalick, F. A. (2019). Improving Nature of Science Instruction in Elementary Classes with Modified Science Trade Books and Educative Curriculum Materials. Journal of Research in Science Teaching, 57(2), 1-30. https://doi.org/10.1002/tea.21588

Çorlu, M. A., \& Corlu, M. S. (2012). Scientific Inquiry Based Professional Development Models in Teacher Education. Educational Sciences: Theory \& Practice, 12(1), 514-521.

Correiro, E. E., Griffin, L. R., \& Hart, P. E. (2008). A Constructivist Approach to Inquiry-Based Learning: A TUNEL Assay for the Detection of Apoptosis in Cheek Cells. American Biology Teacher, 70(8), 457-460.

Darmaji, D., Kurniawan, D. A., \& Irdianti, I. (2019). Physics education students ' science process skills. International Journal of Evaluation and Research in Education, 8(2), 293-298. https://doi.org/10.11591/ijere.v8i2.28646

Dewi, K., Sadia, I. W., \& Ristiati, N. P. (2013). Pengembangan Perangkat Pembelajaran IPA Terpadu dengan Setting Inkuiri Terbimbing untuk Meningkatkan Pemahaman Konsep dan Kinerja Ilmiah Siswa. E-Journal Program Pascasarjana Universitas Pendidikan Ganesha, 3(1), 1-11.

Duschl, R. (2008). Science Education in Three-Part Harmony: Balancing Conceptual, Epistemic, and Social Learning Goals. Review of Research in Education, 32(1), 268-291. https://doi.org/10.3102/0091732X07309371 
Ergul, R., Simsekli, Y., Çalis, S., Özdilek, Z., Gocmencelebi, S., \& Sanli, M. (2011). The Effects of Inquiry-Based Science Teaching on Elementary School Students' Science Process Skills And Science Attitudes. Bulgarian Journal of Science and Education Policy (BJSEP), 5(1), 48-68.

Furtak, E. M., Seidel, T., Iverson, H., \& Briggs, D. (2012). Experimental and Quasi-Experimental Studies of Inquiry-Based Science Teaching: A Meta-Analysis. Review of Educational Research, 82(3), 300-329. https://doi.org/10.3102/0034654312457206

Germann, P. J. (1989). Directed-Inquiry Approach to Learning Science Process Skills: Treatment Effects and AptitudeTreatment Interactions. Journal of Research in Science Teaching, 26(3), 237-250.

Griffin, P., \& Care, E. (2015). Assessment and Teaching of $21^{\text {st }}$ Century Skills. Springer.

Güler, B., \& Şahin, M. (2019). Using Inquiry-Based Experiments to Improve Pre- Service Science Teachers' Science Process Skills. International Journal of Progressive Education, 15(5), 1-18. https://doi.org/10.29329/ijpe.2019.212.1

Gunawan, Harjono, A., Hermansyah, \& Herayanti, L. (2019). Guided Inquiry Model Through Virtual Laboratory to Enhance Students' Science Process Skills on Heat Concept. Cakrawala Pendidikan, 38(2), 259-268. https://doi.org/10.21831/cp.v38i2.23345

Hairida. (2016). The Effectiveness Using Inquiry Based Natural Science Module with Authentic Assessment to Improve The Critical Thinking and Inquiry Skills of Junior High School Students. Jurnal Pendidikan IPA Indonesia, 5(2), $209-215$. https://doi.org/10.15294/jpii.v5i2.7681

Harahap, M. B., Manurung, S. R., Marbun, M. A., \& Mihardi, S. (2016). Effect Model Inquiry Training on Student's Science Process Skill. Advances in Social Sciences Research Journal, 3(11), 38-42.

Iswatun, I., Mosik, M., \& Subali, B. (2017). Penerapan Model Pembelajaran Inkuiri Terbimbing untuk Meningkatkan KPS dan Hasil Belajar Siswa SMP Kelas VIII. Jurnal Inovasi Pendidikan IPA, 3(2), 150-160.

Jalan, S., Nusantara, T., Subanji, S., \& Chandra, T. D. (2016). Students Thinking Process in Solving Combination Problems Considered from Assimilation and Accommodation Framework. Educational Research and Reviews, 11(16), 1494-1499. https://doi.org/10.5897/err2016.2811

Joyce, B. R., \& Weil, M. (2011). Models of Teaching, 8th Edition. Boston: Pearson Education.

Juhji. (2016). Peningkatan Keterampilan Proses Sains Siswa Melalui Pendekatan Inkuiri Terbimbing. Jurnal Penelitian dan Pembelajaran IPA, 2(1), 58-70.

Juniati, N. W., \& Widiana, I. W. (2017). Penerapan Model Pembelajaran Inkuiri untuk Meningkatkan Hasil Belajar IPA. Journal of Education Action Research, 1(2), 122. https://doi.org/10.23887/jear.v1i2.12045

Justice, C., Rice, J., Roy, D., \& Jenkins, B. H. H. (2009). Inquiry-Based Learning in Higher Education: Administrators' Perspectives on Integrating Inquiry Pedagogy into the Curriculum. Higher Education, 58(6), 841-855.

Kara, Y., \& Yeşilyurt, S. (2008). Comparing the Impacts of tutorial and Edutainment Software Programs on Students' Achievements, Misconceptions, and Attitudes Towards Biology. Journal of Science Education and Technology, 17(1), 32-41. https://doi.org/10.1007/s10956-007-9077-z

Kazeni, M. M. M. (2005). Development And Validation of A Test of Integrated Science Process Skills for The Further Education by Degree of Master of Science in Science. University of Pretoria.

Khan, M. (2012). A Comparison of an Inquiry Lab Teaching Method and Traditional Lab Teaching Method Upon Scientific Attitudes of Biology Students. Language in India, 12(1), 398-410.

Koes-H, S., Muhardjito, M., \& Wijaya, C. P. (2018). Scaffolding for Solving Problem in Static Fluid: A Case Study. AIP Conference Proceedings, 1923(030028), 1-9. https://doi.org/10.1063/1.5019519

Koes H., S. (2013). Pengaruh Strategi Scaffolding-Kooperatif dan Pengetahuan Awal terhadap Prestasi Belajar dan Sikap pada Matakuliah Fisika Dasar. Jurnal Pendidikan Humaniora, 1(1), 70-80. https://doi.org/10.17977/jph.v1i1.3979

Kurnia, A. R. D., Ibrahim, M., \& Widodo, W. (2019). Thinking working Scaffolding Sharing Model to Improve Natural Science Competencies for Biology Pre-Service Teachers. (JPBI) Jurnal Pendidikan Biologi Indonesia, 5(2), $325-334$.

Lati, W., Supasorn, S., \& Promarak, V. (2012). Enhancement of Learning Achievement and Integrated Science Process Skills using Science Inquiry Learning Activities of Chemical Reaction Rates. Procedia - Social and Behavioral Sciences, 46, 4471-4475. https://doi.org/10.1016/j.sbspro.2012.06.279

Mantik, O., \& Choi, H. J. (2017). The Effect of Scaffolded Think-Group-Share Learning on Indonesian Elementary Schooler Satisfaction and Learning Achievement in English Classes. International Electronic Journal of Elementary Education, 10(2), 175-183. https://doi.org/10.26822/iejee.2017236113

Martin-hansen, L. M. (2005). Inquiry in Action for Grades 4-8. Science Activities, 41(4), 3-6. https://doi.org/10.3200/SATS.41.4.3-6

Metaputri, N. K., \& Garminah, N. N. (2016). Pengaruh Model Pembelajaran Inkuiri Terbimbing dan Minat Belajar terhadap Keterampilan Proses Sains pada Siswa Kelas IV SD. Jurnal Pendidikan dan Pengajaran, 49(2), 89-97. https://doi.org/10.23887/jppundiksha.v49i2.9013

Minner, D. D., Levy, A. J., \& Century, J. (2009). Inquiry-Based Science Instruction — What Is It and Does It Matter? Results from a Research Synthesis Years 1984 to 2002. Journal of Research in Science Teaching, 47(4).

https://doi.org/10.1002/tea.20347 
Misbah, Wati, M., Rif'at, M. F., \& Prastika, M. D. (2018). Pengembangan Petunjuk Praktikum Fisika Dasar I Berbasis 5M Untuk Melatih Keterampilan Proses Sains dan Karakter Wasaka. Jurnal Fisika FLUX, 15(1), $26-30$.

Muslichach, A. (2006). Penerapan Pendekatan Sains Teknologi Masyarakat dalam Pembelajaran Sains di Sekolah Dasar. Depdiknas.

National, R. C. (1996). National Science Education Standards. National Academy Press.

Nworgu, L. N., \& Otum, V. V. (2013). Effect of Guided Inquiry with Analogy Instructional Strategy on Students Acquisition of Science Process Skills. Journal of Education and Practice, 4(27), 35-41.

Nwosu, A. A., \& Okeke, E. A. C. (1995). The Effects of Teachers' Sensitization of Students' Acquisition of Science Process Skills. Journal of Science Teachers' Association of Nigeria (STAN), 30(1), 39-45.

Perkins, K., Adams, W., Dubson, M., Finkelstein, N., Reid, S., \& Wieman, C. (2006). PhET : Interactive Simulations for Teaching and Learning Physics. The Physics Teacher, 44(1). https://doi.org/10.1119/1.2150754

Piaget, J. (1977). The development of thought: equilibrium of cognitive structures. Viking.

Purnamawati, D., Ertikanto, C., \& Suyatna, A. (2017). Keefektifan Lembar Kerja Siswa Berbasis Inkuiri untuk Menumbuhkan Keterampilan Berpikir Tingkat Tinggi. Jurnal Ilmiah Pendidikan Fisika Al-Biruni, 6(2), 209-219. https://doi.org/10.24042/jipfalbiruni.v6i2.2070

Rizal, M. (2014). Pengaruh Pembelajaran Inkuiri Terbimbing dengan Multi Representasi terhadap Keterampilan Proses Sains dan Penguasaan Konsep IPA Siswa SMP. Jurnal Pendidikan Sains, 2(3), 159-165.

Rustaman, N. Y. (2005). Perkembangan Penelitian Pembelajaran Berbasis Inkuiri dalam Pendidikan Sains. Seminar Nasional II Himpunan Ikatan Sarjana dan Pemerhati Pendidikan IPA Indonesia, 22-23.

Sanjaya, W. (2006). Strategi Pembelajaran Berorientasi Standar Proses Pendidikan. Kencana.

Savitri, E. N., Wusqo, I. U., Ardhi, M. W., \& Putra, P. D. (2017). Enhancement of Science Students' Process Skills Through Implementation of Green Learning Method (Gelem) with Conservation-Based Inquiry Approach. Jurnal Pendidikan IPA Indonesia, 6(2), 237-244. https://doi.org/10.15294/jpii.v6i2.11286

Saye, J. W., \& Brush, T. (2002). Scaffolding Critical Reasoning about History and Social Issues in Multimedia-Supported Learning Environments. Educational Technology Research and Development, 50(3), 77-96. https://doi.org/10.1007/BF02505026

Setyawati, N. W. I., Candiasa, M., \& Yudana, I. M. (2014). Pengaruh Model Pembelajaran Inkuiri Terbimbing terhadap Pemahaman Konsep dan Keterampilan Proses Sains Siswa Kelas XI IPA SMA Negeri 2 Kuta Kabupaten Badung. Jurnal Administrasi Pendidikan UNDIKSHA, 5(1), 1-9.

Shahali, E. H. M., Halim, L., Treagust, D. F., Won, M., \& Chandrasegaran, A. L. (2015). Primary School Teachers' Understanding of Science Process Skills in Relation to Their Teaching Qualifications and Teaching Experience. Research in Science Education, 47(2), 257-281. https://doi.org/10.1007/s11165-015-9500-z

Simons, K. D., \& Klein, J. D. (2007). The Impact of Scaffolding and Student Achievement Levels in a Problem-Based Learning Environment. Instructional Science, 35(1), 41-72. https://doi.org/10.1007/s11251-006-9002-5

Simsek, P., \& Kabapinar, F. (2010). The Effects of Inquiry-Based Learning on Elementary Students' Conceptual Understanding of Matter, Scientific Process Skills and Science Attitudes. Procedia Social and Behavioral Sciences, 2(2), 1190-1194. https://doi.org/10.1016/j.sbspro.2010.03.170

Slavin, R. E. (2006). Educational Psychology Teory and Practice. Boston: Pearson Education.

Sribekti, A., Ibrohim, \& Hidayat, A. (2016). Peningkatan Keterampilan Proses Sains dan Hasil Belajar Kognitif Siswa Kelas VII SMP Negeri 1 Selorejo menggunakan Perangkat Pembelajaran Ekosistem Berbasis Inkuiri Terbimbing dengan Sumber Belajar Waduk Lahor. Jurnal Pendidikan: Teori, Penelitian, dan Pengembangan, 1(8), 1575-1580.

Sullivan, F. R. (2008). Robotics and Science Literacy: Thinking Skills, Science Process Skills and Systems Understanding. Journal of Research in Science Teaching, 45(3), 373-394. https://doi.org/10.1002/tea

Sund, R. B., \& Trowbridge, L. W. (1973). Teaching Science by Inquiry in the Secondary School Second Edition. Merill Books.

Suparno, P. (2013). Miskonsepsi dan Perubahan Konsep dalam Pendidikan Fisika. PT. Grasindo.

Suyono, \& Hariyanto. (2012). Belajar dan Pembelajaran Teori dan Konsep Dasar. PT Remaja Rosdakarya.

Tangkas, I. M. (2012). Pengaruh Implementasi Model Pembelajaran Inkuiri Terbimbing terhadap Kemampuan Pemahaman Konsep dan Keterampilan Proses Sains Siswa Kelas X SMAN 3 Amlapura. Jurnal Pendidikan dan Pembelajaran IPA Indonesia, 2(1), 1-17.

Tilakaratne, C. T. K., \& Ekanayake, T. M. S. S. K. Y. (2017). Achievement level of Science Process Skills of Junior Secondary Students : Based on a Sample of Grade Six and Seven Students from Sri Lanka. International Journal of Environmental \& Science Education, 12(9), 2089-2108.

Ting, K. L., \& Siew, N. M. (2014). Effects of Outdoor School Ground Lessons on Students' Science Process Skills and Scientific Curiosity. Journal of Education and Learning, 3(4), 96-107. https://doi.org/10.5539/jel.v3n4p96

Trianto. (2009). Strategi Pembelajaran Inovatif Kontemporer. Jakarta: Bumi Aksara.

Tursinawati. (2016). Penguasaan Konsep Hakikat Sains dalam Pelaksanaan Percobaan Pada Pembelajaran IPA di SDN Kota Banda Aceh. Jurnal Pesona Dasar, 2(4), 72-84. 
Van-Dijk, A. M., \& Lazonder, A. W. (2016). Scaffolding Students' Use of Learner-Generated Content in a TechnologyEnhanced Inquiry Learning Environment. Interactive Learning Environments, 24(1), 194-204. https://doi.org/10.1080/10494820.2013.834828

Van-Uum, M. S. J., Verhoeff, R. P., \& Peeters, M. (2017). Inquiry-Based Science Education: Scaffolding Pupils' Self-Directed Learning in Open Inquiry. International Journal of Science Education, 39(18), 2461-2481. https://doi.org/10.1080/09500693.2017.1388940

Warpala, I. W. S. (2006). Pengaruh Pendekatan Pembelajaran dan Stategi Belajar Kooperatif yang Berbeda terhadap Pemahaman dan Keterampilan Berpikir Kritis dalam Pembelajaran IPA SD. Universitas Negeri Malang.

Wijayaningputri, A. R., Widodo, W., \& Munasir. (2018). The Effect of Guided-Inquiry Model on Science Process Skills Indicators. (JPPS) Jurnal Penelitian Pendidikan Sains, 8(1), 1542-1546.

Yager, R. E., \& Akcay, H. (2010). The Advantages of an Inquiry Approach for Science Instruction in Middle Grades. School Science and Mathematics, 110(1), 5-12. https://doi.org/10.1111/j.1949-8594.2009.00002.x

Yakar, Z., \& Baykara, H. (2014). Inquiry-Based Laboratory Practices in a Science Teacher Training Program. Eurasia Journal of Mathematics, Science \& Technology Education, 10(2), 173-183. https://doi.org/10.12973/eurasia.2014.1058a

Yildirim, A. (2012). Effect Of Guided Inquiry Experiments On The Acquisition Of. Midle East Technical University.

Yumuşak, G. K. (2016). Science Process Skills in Science Curricula Applied in Turkey. Journal of Education and Practice, 7(20), 94-98.

Zeidan, A. H., \& Jayosi, M. R. (2015). Science Process Skills and Attitudes toward Science among Palestinian Secondary School Students. World Journal of Education, 5(1), 13-24. https://doi.org/10.5430/wje.v5n1p13 